\title{
OPTIMASI PERENCANAAN PRODUKSI DENGAN MENGGUNAKAN METODE LINEAR PROGRAMMING PADA CV. ACEH BAKERY
}

\author{
Ria Asysyfa Hasni \\ Dosen Jurusan Teknik Industri Fakultas Teknik UTU \\ $\underline{\text { Ria.asysyfa@yahoo.com }}$
}

\begin{abstract}
One purpose is to review company get advantages The Maximum and minimum cover charge thing. Many HAL should be made for a review of A Company Posted achieve these objectives, ie only prayer is how to determine Products Should TYPE WITH generated utilizing existing resources thus able to contribute Maximum AGRO. Company Must Develop CAN BE Meticulously Term Planning Production will be produced for review optimize profits WITH take into account factors such as the production of raw materials. When Paid Products produced too big Namely State exceeds the demand limit, then HAL husband will result in inaccuracies allocate factors of production is owned, thereby increasing the cost of production includes. Here Writers Wanted Looking for an alternative solution to a review AS WITH planned increase profits Production WITH progamming optimal linear method.

The findings of The TIN using software TORA BY TYPE findings For green bread, CV. Aceh Bakery Must be producing as much as 152 packs / day. For TYPE bread Skinless, CV. Aceh Bakery Must be producing as much as 149 packs / day. For TYPE crusted bread, CV. Aceh Bakery Must be producing 150 packs / day. Article Search Google so, then CV. Aceh Bakery will get a profit of Rp.1.973.100, - / day.
\end{abstract}

Keyword : Roti, Optimization, Linier Proggramming, TORA.

\section{PENDAHULUAN}

CV. Aceh Bakery, Lhokseumawe, yang merupakan perusahaan manufaktur. Perusahaan ini memproduksi roti yang mana bahan baku utama yang menunjang jalannya produksi adalah tepung terigu. Hasil produksi perusahaan dipasarkan didalam dan di luar daerah yaitu geudong dan bireun. Dalam menjalankan aktifitas produksinya, tentu saja CV. Aceh Bakery membutuhkan suatu perencanaan dalam mengalokasikan sumbersumber daya yang tersedia.

Salah satu tujuan perusahaan adalah untuk mendapatkan keuntungan yang maksimum dan biaya yang minimum. Banyak hal harus dilakukan oleh suatu perusahaan untuk mencapai tujuan tersebut, yaitu salah satunya adalah bagaimana menentukan jenis produk yang harus dihasilkan dengan memamfaatkan sumber daya yang ada sehingga mampu memberikan kontribusi maksimum laba.

Berdasarkan masalah yang pernah dialami perusahaan mengenai bertambahnya pabrik roti sehinga bertambahnya persaingan pasar yang cukup pesat, perusahaan harus 
dapat menyusun secara cermat perencanaan jumlah produksi yang akan diproduksikan untuk mengoptimalkan keuntungan dengan memperhitungkan faktor-faktor produksi seperti bahan baku. Apabila jumlah produk yang dihasilkan terlalu besar yaitu melebihi batas permintaan, maka hal ini akan megakibatkan ketidaktepatan mengalokasikan faktorfaktor produksi yang dimiliki, sehingga akan meningkatkan biaya produksi.

\section{KAJIAN LITERATUR}

\subsection{Biaya Pabrikasi}

Biaya pabrikasi (manufaktur) meliputi semua biaya yang berkaitan dengan proses produksi. Biaya pabrikasi umumnya dibagi dalam tiga komponen yaitu, (Henry Simamura, 2002):
a. Biaya Bahan Langsung
b. Biaya Tenaga Kerja Langsung
c. Biaya Tidak Langsung Pabrik (Biaya Overhead Pabrik)

\subsection{Jenis-Jenis Biaya}

Pada umumnya ada dua biaya yaitu biaya tetap (fixed cost) dan biaya tidak tetap (Variable cost) pabrikasi, (Siswanto sutojo, 2001)
a. Biaya Tetap (Fixed cost)
b. Biaya Tidak tetap (Variable cost)

\subsection{Harga Pokok Produksi (HPP)}

Suatu perusahaan perlu mengetahui tentang besarnya harga pokok produksi yang dihasilkan karena informasi ini dapat dijadikan sebagai salah satu pedoman dalam menentukan harga jual maupun untuk memperkirakan berapa keuntungan yang akan diperoleh dari hasil penjualan barang tersebut. (Mulyadi, 2000),

Harga pokok produksi yang dihitung adalah harga pokok per unit dari masingmasing jenis produk, yaitu:

\begin{tabular}{ll} 
Biaya bahan baku langsung & Rp. xxxx \\
Biaya tenaga kerja langsung & Rp. xxxx \\
Biaya overhead pabrik & Rp. xxxx \\
\cline { 2 - 2 } & Rp. xxxx
\end{tabular}

\subsection{Marginal Income}

Marginal income adalah kelebihan pendapatan setelah dikurangi biaya berubah atau suatu jumlah tertentu untuk menutupi biaya tetap dan memperoleh laba. Marginal Income 
(MI) adalah harga jual (HJ) dikurangi dengan harga pokok produksi (HPP). Model matematikanya adalah, (Siswanto sutojo, 2001):

$$
\begin{aligned}
& \text { MIi = HJi }- \text { HPPi } \\
& \text { Dimana: } \\
& \text { MIi = marginal income perunit untuk produk } \mathrm{i} \\
& \mathrm{HJi}=\text { harga jual unit untuk produk } \mathrm{i} \\
& \mathrm{HPPi}=\text { harga pokok produksi perunit untuk produk } \mathrm{i}
\end{aligned}
$$

\subsection{Waktu Siklus}

Waktu siklus merupakan waktu rata-rata yang dibutuhkan seluruh waktu pengamatan untuk tiap jenis produk. (Eddy herjanto, 1997).

$$
\begin{aligned}
& \text { Waktu siklus }=\frac{\sum X i}{N} \\
& \text { Dimana: } \\
& \begin{array}{ll}
\sum X i \quad=\text { jumlah waktu untuk tiap unit ke } \mathrm{i} \\
\mathrm{N} \quad=\text { jumlah pengamatan }
\end{array}
\end{aligned}
$$

\subsection{Linier Proggramming}

Linear Programming adalah sebuah alat deterministik, yang berarti bahwa sebuah parameter model diasumsikan diketahui dengan pasti. Tetapi dalam kehidupan nyata, jarang seseorang menghadapi masalah di mana terdapat kepastian yang sesungguhnya. Teknik Linear Programming mengkompetisi "kekurangan" ini dengan memberikan analisis pasca-optimum dan analisa parametrik yang sistematis untuk memungkinkan pengambil keputusan yang bersangkutan untuk menguji sensitivitas pemecahan optimum yang statis terhadap perubahan diskrit atau kontiniu dalam berbagai parameter dari model tersebut. Pada intinya, teknik tambahan ini memberikan dimensi dinamis pada sifat pemecahan Linear Programming yang optimum.

Linear Programming merupakan proses optimasi dengan menggunakan model keputusan yang dapat diformulasikan secara matematis dan timbul karena adanya keterbatasan dalam mengalokasikan sumber - sumber daya. Don T. Philips dalam bukunya "Operations Research and Principle", menyatakan bahwa Linear Programming merupakan masalah pemograman yang harus memenuhi tiga kondisi berikut:

1. Variabel-variabel keputusan yang terlibat harus positif 
2. Kriteria-kriteria untuk memilih nilai terbaik dari variabel keputusan dapat diekspresikan sebagai fungsi linear. Fungsi kriteria ini biasa disebut "fungsi objektif"

3. Aturan-aturan operasi yang mengarahkan proses-proses dapat diekspresikan sebagai suatu set persamaan atau pertidaksamaan linear. Set tersebut dinamakan fungsi pembatas. (Don philips, 1996)

Metode Linear programming dapat diselesaikan dengan 2 cara metode yaitu:

1. Metode Grafik

Metode grafik merupakan suatu metode yang digunakan untuk memecahkan persoalan linear dengan dua variabel. Sedangkan untuk tiga variabel atau lebih dapat digunakan dengan menggunakan metode simpleks. Dengan metode grafik ini diperoleh beberapa aspek penting dari model program linear dapat dengan mudah digambarkan. Tujuan dari pembahasan pemecahan masalah model program linear dengan metode grafik adalah untuk mengetahui hubunganhubungan kendala dalam program linear.

Langkah-langkah penyelesaian Linear programming dengan metode grafik yaitu:

a. Formulasikan masalah kedalam bentuk matematis.

b. Gambarkan masing-masing garis kendala dalam satu sistem pada garis sumbu koordinat.

c. Cari titik yang paling menguntungkan dihubungkan dengan fungsi tujuan

2. Metode Simpleks

Metode simpleks merupakan suatu metode yang secara sistematis dimulai dari suatu pemecahan dasar yang dilakukan berulang-ulang sehingga akhirnya tercapai suatu pemecahan dasar yang optimum dan pada setiap step menghasilkan suatu nilai fungsi tujuan yang selalu lebih besa /lebih kecil atau sama dari step-step lainnya. Langkah-langkah penyelesaian metode simpleks adalah sebagai berikut :

1. Periksa apakah tabel layak atau tidak. Kelayakan tabel simpleks dilihat dari solusi (nilai kanan). Jika solusi ada yang bernilai negatif, maka tabel tidak layak. Tabel yang tidak layak tidak dapat diteruskan untuk dioptimalkan.

2. Tentukan kolom pivot. Penentuan kolom pivot dilihat dari koefisien fungsi tujuan (nilai di sebelah kanan baris z) dan tergantung dari bentuk tujuan. Jika tujuan maksimisasi, maka kolom pivot adalah kolom dengan koefisien paling negatif. Jika tujuan minimisasi, maka kolom pivot adalah kolom dengan 
koefisien positif terbesar. Jika kolom pivot ditandai dan ditarik ke atas, maka kita akan mendapatkan variabel keluar. Jika nilai paling negatif (untuk tujuan maksimisasi) atau positif terbesar (untuk tujuan minimisasi) lebih dari satu, pilih salah satu secara sembarang.

3. Tentukan baris pivot. Baris pivot ditentukan setelah membagi nilai solusi dengan nilai kolom pivot yang bersesuaian (nilai yang terletak dalam satu baris). Dalam hal ini, nilai negatif dan 0 pada kolom pivot tidak diperhatikan, artinya tidak ikut menjadi pembagi. Baris pivot adalah baris dengan rasio pembagian terkecil. Jika baris pivot ditandai dan ditarik ke kiri, maka kita akan mendapatkan variabl keluar. Jika rasio pembagian terkecil lebih dari satu, pilih salah sau secara sembarang.

4. Tentukan elemen pivot. Elemen pivot merupakan nilai yang terletak pada perpotongan kolom dan baris pivot.

5. Bentuk tabel simpleks baru. Tabel simpleks baru dibentuk dengan pertama sekali menghitung nilai baris pivot baru. Baris pivot baru adalah baris pivot lama dibagi dengan elemen pivot. Baris baru lainnya merupakan pengurangan nilai kolom pivot baris yang bersangkutan dikali baris pivot baru dalam satu kolom terhadap baris lamanya yang terletak pada kolom tersebut.

6. Periksa apakah tabel sudah optimal. Keoptimalan tabel dilihat dari koefisien fungsi tujuan (nilai pada baris z) dan tergantung dari bentuk tujuan. Untuk tujuan maksimisasi, tabel sudah optimal jika semua nilai pada baris z sudah positif atau 0. Pada tujuan minimisasi, tabel sudah optimal jika semua nilai pada baris z sudah negatif atau 0. Jika belum, kembali ke langkah no. 2 , jika sudah optimal baca solusi optimalnya. (Siringoringo, Hotniar. 2005)

\section{METODOLOGI}

\subsection{Pengumpulan Data}

Pengumpulan data adalah suatu teknik pengumpulan informasi-informasi yang dilakukan untuk mendapatkan sebuah data yang digunakan sebagai bahan untuk membuat sebuah penelitian. Pengumpulan data memiliki tujuan sebagai solusi yang tepat dari persoalan yang dihadapi setelah dilakukannya pengolahan data terhadap data yang diambil sebagai bahan dalam penelitian, daalm penelitian ini data yang diambil adalah:

1. Jenis-jenis produk

2. Data hasil produksi 
3. Data jumlah permintaan

4. Data jumlah hari kerja

5. Data kecepatan produksi

6. Kapasitas mesin

\subsection{Defenisi Operasional Variabel Penelitian}

Beberapa variabel operasional yang digunakan dalam penelitian ini adalah:

a. Linear proggramming merupakan proses optimasi dengan menggunakan model keputusan yang dapat diformulasikan secara matematis dan timbul karena adanya keterbatasan dalam mengalokasikan sumber-sumber daya.

b. Biaya pabrikasi adalah semua biaya yang berkaitan dengan proses produksi.

c. Marginal income adalah kelebihan pendapatan setelah dikurangi biaya berubah atau suatu jumlah tertentu untuk menutupi biaya tetap dan memperoleh laba.

d. Waktu siklus adalah waktu rata-rata yang dibutuhkan seluruh waktu pengamatan untuk tiap jenis produk.

\section{HASIL DAN DISKUSI}

\section{PENGOLAHAN DATA}

1. Pengukuran Waktu Kecepatan (Waktu Siklus)

Pengukuran waktu kecepatan yaitu waktu siklus yang digunakan dalam pengamatan adalah waktu pada pengolahan roti untuk masing-masing jenis produk dapat dilihat pada tabel 4.1.

Tabel 4.1. Kecepatan Produksi Roti

\begin{tabular}{cccc}
\hline Volume pengamatan & \multicolumn{3}{c}{ Kecepatan produksi jenis Roti (menit/bungkus) } \\
Roti berwarna & $\begin{array}{c}\text { Roti tanpa } \\
\text { hijau }\end{array}$ & Roti berkulit \\
\hline 1 & 7,31 & 7,31 & 7,31 \\
2 & 8,00 & 8,00 & 8,00 \\
3 & 7,23 & 7,23 & 7,23 \\
4 & 6,89 & 6,89 & 6,89 \\
5 & 7,20 & 7,20 & 7,20 \\
6 & 7,25 & 7,25 & 7,25 \\
7 & 7,08 & 7,08 & 7,08 \\
8 & 7,30 & 7,30 & 7,30 \\
9 & 7,25 & 7,25 & 7,25 \\
10 & 7,15 & 7,15 & 7,15 \\
\hline
\end{tabular}

Dari tabel 4.1. diketahui bahwa waktu siklus untuk produksi Roti berwarna hijau, tanpa kulit dan berkulit adalah : 


$$
\mathrm{WS}=\frac{\sum X i}{N}
$$

1. Roti bantal berwana hijau

$$
\begin{aligned}
& \mathrm{WS}=\frac{\sum X i}{N} \\
& \mathrm{WS}=\frac{72,66}{10}=7,26 \text { menit/bungkus }
\end{aligned}
$$

2. Roti bantal tanpa kulit

$$
\begin{aligned}
& \mathrm{WS}=\frac{\sum X i}{N} \\
& \mathrm{WS}=\frac{72,66}{10}=7,26 \text { menit/bungkus }
\end{aligned}
$$

3. Roti bantal berkulit

$$
\begin{aligned}
& \mathrm{WS}=\frac{\sum X i}{N} \\
& \mathrm{WS}=\frac{72,66}{10}=7,26 \text { menit/bungkus }
\end{aligned}
$$

\section{Penentuan Marginal Income}

Untuk mengitung jumlah marginal income setiap jenis produk maka dihitung biaya bahan baku langsung, biaya tenaga kerja langsung dan biaya overhead pabrik dengan data sebagai berikut :

1. Biaya Bahan Baku Langsung

Untuk jenis produk roti bantal, perhitungan biaya bahan baku langsung dicantum dalam tabel 4.2.

Tabel 4.2. Perincian Biaya Bahan Baku Langsung Roti bantal perbungkus

\begin{tabular}{llccc}
\hline No & Komponen & Jumlah & $\begin{array}{c}\text { Harga } \\
\text { Satuan } \\
(\mathbf{R p} / \mathbf{K g})\end{array}$ & $\begin{array}{c}\text { Total } \\
(\mathbf{R p})\end{array}$ \\
\hline $1 \quad$ Bahan baku & & & \\
\hline & Tepung terigu & $220 \mathrm{gr}$ & 5.000 & 1100 \\
& Gula & $70 \mathrm{gr}$ & 10.000 & 700 \\
& Telur & $39,2 \mathrm{gr}$ & 800 & 31,36 \\
& Susu bubuk & $2,6 \mathrm{gr}$ & 40.000 & 104 \\
& Butter & $3,5 \mathrm{gr}$ & 20.000 & 70 \\
Giss & $0,8 \mathrm{gr}$ & 30.000 & 24 \\
& Mentega & $8,82 \mathrm{gr}$ & 13.000 & 115 \\
\hline & \multicolumn{3}{c}{} & 2144,36 \\
\hline 2 & Bahan penolong & Total & 158 & 17 \\
& Air & $110,2 \mathrm{gr}$ & 0,2 \\
& Pewarna makanan & $0,01 \mathrm{gr}$ & 20.000 & 0,5 \\
& Pengawet makanan & $0,001 \mathrm{gr}$ & 500.000 & 0,002 \\
Aroma & $0,01 \mathrm{gr}$ & 2000 & 17,702 \\
\hline
\end{tabular}




\begin{tabular}{llccc}
\hline No & Komponen & Jumlah & $\begin{array}{c}\text { Harga } \\
\text { satuan } \\
(\mathbf{R p} / \mathbf{K g})\end{array}$ & $\begin{array}{c}\text { Total } \\
(\mathbf{R p})\end{array}$ \\
\hline 3 & Bahan tambahan & & \\
\hline & Plastik & & & 0,85 \\
& Perekat & $0,17 \mathrm{gr}$ & 5.000 & 0,25 \\
& & $0,05 \mathrm{gr}$ & 5.000 & 1,1 \\
& & & $2.163,162$ \\
\hline
\end{tabular}

Sumber : CV Aceh Bakery (diolah)

Daftar dari tabel diatas adalah biaya bahan baku langsung untuk ketiga jenis produk. Jadi kesimpulan keseluruhan hasil biaya bahan baku langsung untuk setiap jenis produk dapat dilihat pada tabel 4.3.

Tabel 4.3. Hasil Biaya Bahan Baku Langsung Untuk Setiap Produk/bungkus

\begin{tabular}{lc}
\hline \multicolumn{1}{c}{ Jenis produk } & $\begin{array}{c}\text { Biaya bahan baku } \\
\text { (Rp/bungkus) }\end{array}$ \\
\hline Roti berwarna hijau & $2.163,162$ \\
Roti tanpa kulit & $2.163,162$ \\
Roti berkulit & $2.163,162$ \\
\hline
\end{tabular}

2. Biaya Tenaga Kerja Langsung

a. Untuk jenis Roti berwarna hijau

Biaya tenaga kerja langsung sesuai dengan UMP (Upah minimum Produksi) sebesar Rp. 40.000/hari atau Rp.5.000/jam. Jumlah tenaga kerja 5 orang. Jumlah produksi yang dihasilkan perjam adalah 152/8= 19 bungkus/jam. Maka biaya tenaga kerja yang dibutuhkan untuk menghasilkan 1 bungkus roti adalah :

$=\frac{\text { jumlah tenaga kerja } \mathrm{x} \text { upah per jam }}{\text { jumlah yang dihasilkan per jam }}$

$=\frac{5 \text { orang } \times 5000 / \mathrm{jam} / \text { orang }}{19 \text { bungkus/ja m }}$

$=70 /$ bungkus

b. Untuk jenis Roti tanpa kulit

Biaya tenaga kerja langsung sesuai dengan UMP (Upah minimum Produksi) sebesar Rp. 40.000/hari atau Rp.5.000/jam. Jumlah tenaga kerja 5 orang. Jumlah produksi yang dihasilkan perjam adalah 152/8=19 bungkus/jam. Maka biaya tenaga kerja yang dibutuhkan untuk menghasilkan 1 bungkus roti adalah :

$=\frac{\text { jumlah tenaga kerja } \mathrm{x} \text { upah per jam }}{\text { jumlah yang dihasilkan per jam }}$ 


$$
\begin{aligned}
& =\frac{5 \text { orang } \times 5000 / \text { jam} / \text { orang }}{19 \text { bungkus } / \text { jam }} \\
& =70 / \text { bungkus }
\end{aligned}
$$

c. Untuk jenis Roti berkulit

Biaya tenaga kerja langsung sesuai dengan UMP (Upah minimum Produksi) sebesar Rp. 40.000/hari atau Rp.5.000/jam. Jumlah tenaga kerja 5 orang. Jumlah produksi yang dihasilkan perjam adalah 150/8=19 bungkus/jam. Maka biaya tenaga kerja yang dibutuhkan untuk menghasilkan 1 bungkus roti adalah :

$=\frac{\text { jumlah tenaga kerja } \mathrm{x} \text { upah per jam }}{\text { jumlah yang dihasilkan per jam }}$

$=\frac{5 \text { orang } \times 5000 / \text { jam } / \text { orang }}{19 \text { bungkus } / \text { jam }}$

$=70$ /bungkus

3. Biaya Overhead Pabrik

Roti berwarna hijau yang di hasilkan rata-rata perhari adalah 152 bungkus, Roti tanpa kulit 152 bungkus, dan roti berkulit 150 bungkus. Untuk biaya overhead pabrik perbulan meliputi biaya listrik, perawatan mesin, pajak bumi dan bangunan serta biaya telepon seperti yang dijelaskan dibawah ini:

- Listrik :Rp. 250.000

- Perawatan mesin : Rp. 300.000

- Pajak bumi dan bangunan : Rp. 50.000

- Telepon $\quad$ :Rp. 150.000

Rp. 750.000

Untuk biaya satu bungkus roti berwarna hijau adalah Rp. 750.000/26 hari/ 152 bungkus adalah Rp. 189,77,-- per bungkus. Untuk biaya satu bungkus roti tanpa kulit adalah Rp. 750.000/26 hari/ 152 bungkus adalah Rp. 189,77,- per bungkus. Untuk biaya satu bungkus roti berkulit adalah Rp. 750.000/26 hari/ 150 bungkus adalah Rp. 192,30,- per bungkus

3 Perhitungan Harga Pokok Produksi

Harga pokok produksi yang dihitung adalah harga pokok dari masing-masing produk adalah :

1. Harga pokok produksi untuk jenis roti berwarna hijau

- Biaya bahan baku

Rp. $2.163,162$ 
- Biaya tenaga kerja langsung Rp. 70

- $\quad$ Biaya overhead pabrik Rp. 189,77

Total harga pokok produksi $\quad$ Rp. 2.422,932

2. Harga pokok produksi untuk jenis roti tanpa kulit

- Biaya bahan baku

Rp. $2.163,162$

- Biaya tenaga kerja langsung Rp. 70

- $\quad$ Biaya overhead pabrik Rp. 189,77

Total harga pokok produksi Rp. 2.422,932

3. Harga pokok produksi untuk jenis roti berkulit

- Biaya bahan baku

Rp. $2.163,162$

- Biaya tenaga kerja langsung Rp. 70

- Biaya overhead pabrik Rp. 192,30

Total harga pokok produksi Rp. 2.425,462

Tujuan dari kerja praktek ini adalah untuk memaksimumkan keuntungan bagi perusahaan. Karena metode penyelesaiannya dengan program linear. Maka keuntungan yang dihitung adalah marginal income (MI). MI adalah kelebihan pendapatan setelah dikurangi biaya berubah (harga pokok produksi) atau suatu jumlah tertentu untuk menutupi biaya tetap dan memperoleh laba. Marginal income per bungkus (MI) adalah harga jual perbungkus (HJ) dikurangi dengan harga pokok produksi perbungkus (HPP). Maka nilai marginal income perbungkus untuk tiap jenis roti bantal adalah :

a. Untuk jenis roti berwarna hijau

$$
\begin{aligned}
\mathrm{MJi} & =\mathrm{Hji}-\mathrm{HPPi} \\
& =\mathrm{Rp} .8 \cdot 500 / \text { bungkus }-2.422,932 / \text { bungkus } \\
& =\text { Rp. } 6.077
\end{aligned}
$$

b. Untuk jenis roti tanpa kulit

$$
\begin{aligned}
\mathrm{MJi} & =\mathrm{Hji}-\mathrm{HPPi} \\
& =\text { Rp. } 9.000 / \text { bungkus }-2.422,932 \text { /bungkus } \\
& =\text { Rp. } 6.577
\end{aligned}
$$

c. Untuk jenis roti berkulit

$$
\begin{aligned}
\mathrm{MJi} & =\mathrm{Hji}-\mathrm{HPPi} \\
& =\text { Rp. } 8.000 / \text { bungkus }-2.425,462 \text { /bungkus } \\
& =\text { Rp. } 5.575
\end{aligned}
$$


4 Perhitungan dengan Menggunakan Linear Programming

Penyelesaian masalah perencanaan produksi dilakukan dengan aplikasi ilmu Operation Research (Linear Programming)

1. Penentan Variabel Keputusan

Tujuan penyelesaian permasalahan adalah untuk menentukan volume produksi setiap jenis produk dalam jangka waktu satu tahun, variabel keputusannya dapat diasumsikan sebagai berikut :

$\mathrm{X} 1=$ Jumlah produksi untuk jenis roti berwarna hijau (bungkus/hari)

$\mathrm{X} 2=$ Jumlah produksi untuk jenis roti tanpa kulit bulan (bungkus/hari)

X3 = Jumlah produksi untuk jenis roti berkulit (bungkus/hari)

2. Penentuan dan Perumusan Fungsi Tujuan

Fungsi tujuan dalam masalah ini adalah untuk memaksimumkan total marginal income perusahaan. $\mathrm{Z}$ dinyatakan sebagai total marginal income (Rupiah). Maka fungsi tujuan dapat diformulasikan sebagai berikut:

$$
\begin{aligned}
& \operatorname{Max} Z=\sum_{j=1}^{n} \mathrm{C} 1 . \mathrm{X} 1 \\
& \operatorname{Max} \mathrm{Z}=\mathrm{C} 1 \mathrm{X} 1+\mathrm{C} 2 \mathrm{X} 2+\mathrm{C} 3 \mathrm{X} 3
\end{aligned}
$$

Dimana:

$\mathrm{C} 1=$ Marginal income untuk jenis roti berwarna hijau (Rupiah)

C2 = Marginal income untuk jenis roti tanpa kulit (Rupiah)

C3 = Marginal income untuk jenis roti berkulit (Rupiah)

Jadi fungsi tujuan dapat diformulasikan sebagai berikut:

$\operatorname{Max} Z=6.077 \mathrm{X} 1+6.577 \mathrm{X} 2+5.575 \mathrm{X} 3$

3. Fungsi pembatas

\begin{tabular}{|c|c|c|c|c|}
\hline \multirow{2}{*}{$\begin{array}{l}\text { Kegiatan } \\
\text { Sumber daya } \\
\text { Bahan baku }\end{array}$} & \multicolumn{3}{|c|}{ Aktivitas (unit roti) } & \multirow{2}{*}{ Kapasitas/hari } \\
\hline & $\mathrm{X} 1$ & $\mathrm{X} 2$ & $\mathbf{X 3}$ & \\
\hline Tepung terigu & 220 (gr) & 220 (gr) & 220 (gr) & $18700 \mathrm{gr}$ \\
\hline Gula & $70(\mathrm{gr})$ & $70(\mathrm{gr})$ & $70(\mathrm{gr})$ & $5950 \mathrm{gr}$ \\
\hline Telur & $39,2(\mathrm{gr})$ & $39,2(\mathrm{gr})$ & $39,2(\mathrm{gr})$ & $3332 \mathrm{gr}$ \\
\hline \multicolumn{5}{|l|}{ Mesin } \\
\hline Mesin pengadon & 40 bungkus & 40 bungkus & 40 bungkus & 120 bungkus \\
\hline Pemanggang & 12 bungkus & 12 bungkus & 12 bungkus & 120 bungkus \\
\hline Mesin pemotong & 40 bungkus & 40 bungkus & 40 bungkus & 120 bungkus \\
\hline Mesin pengemas & 40 bungkus & 40 bungkus & 40 bungkus & 120 bungkus \\
\hline Tenaga kerja & 7,26 menit & 7,26 menit & 7,26 menit & 2400 menit \\
\hline
\end{tabular}

Tabel 4.4: Tabel fungsi pembatas 
a. Batasan bahan baku

Bahan baku yang dipergunakan untuk memproduksi pengolahan roti bantal adalah tepung terigu, gula dan telur. Kebutuhan tepung terigu yang diperlukan CV. Aceh Bakery adalah 18700 gr/hari, gula sebanyak 5950 gr/hari, telur sebanyak 3332 gr/hari. Sedangkan kebutuhan koefisien bahan baku tepung untuk memproduksi 1 bungkus roti adalah 220 gr, untuk gula 70 gr dan untuk telur 39,2 gr. sehingga batasan bahan bakunya adalah sebagai berikut :

1. $220 \mathrm{X} 1+220 \mathrm{X} 2+220 \mathrm{X} 3 \leq 18700$

2. $70 \times 1+70 \times 2+70 \times 3 \leq 5950$

3. $39,2 \mathrm{X} 1+39,2 \mathrm{X} 2+39.2 \mathrm{X} 3 \leq 3332$

b. Batasan kapasitas mesin

Mesin yang digunakan untuk proses produksi roti bantal adalah mesin pengadon, pemanggang, mesin pemotong dan mesin pengemas yang masing-masingnya berkapasitas 120 bungkus/hari. Maka batasan kapasitas mesin adalah:

1. $40 \times 1+40 \times 2+40 \times 3 \leq 120$

2. $12 \times 1+12 \times 2+12 \times 3 \leq 120$

3. $40 \times 1+40 \times 2+40 \times 3 \leq 120$

4. $40 \times 1+40 \times 2+40 \times 3 \leq 120$

c. Batasan tenaga kerja

Tenaga kerja yang ada pada CV. Aceh Bakery terdiri dari 5 orang, setiap tenaga kerja mampu menghasilkan 20 bungkus/hari. Maka batasan tenaga kerja adalah $7,26 \mathrm{X} 1+7,26 \mathrm{X} 2+7,26 \mathrm{X} 3 \leq 2400$

d. Batasan permintaan

Rata-rata jumlah permintaan untuk jenis roti berwarna hijau adalah 4552 bungkus/bulan $=86$ bungkus/hari

Rata-rata jumlah permintaan untuk jenis roti tanpa kulit adalah 4551 bungkus/bulan $=85$ bungkus $/$ hari

Rata-rata jumlah permintaan untuk jenis roti berkulit adalah 4467 bungkus/bulan = 85 bungkus/hari

Maka batasan untuk permintaan adalah:

$\mathrm{X}_{1} \leq 152$

$\mathrm{X}_{2} \leq 152$

$\mathrm{X}_{3} \leq 150$ 


\section{Penyelesaian Masalah dengan Menggunakan Linear Programming}

Setelah fungsi tujuan dan fungsi pembatas diformulasikan secara lengkap, maka dilakukan penyelesaian masalah dengan linear prongramming. Perhitungannya tidak dilakukan secara manual tetapi melakukan perhitungan dengan software TORA Optimization System, windows-version 1.00. untuk penyelesaian yang lebih cepat, tepat dan teliti.

a. Analisa Hasil

1. analisa Pengukuran Waktu Siklus

Dalam menentukan waktu siklus untuk tiap jenis roti. Maka diperoleh waktu siklus untuk jenis roti berwarna hijau adalah 7,26 menit/bungkus, untuk jenis roti tanpa kulit adalah 7,26 menit/bungkus dan untuk roti jenis berkulit adalah 7,26 menit/bungkus.

2. Analisa Penentuan Marginal Income

Untuk menentukan marginal income maka harus dihitung biaya bahan baku langsung, biaya tenaga kerja langsung dan biaya overhead pabrik. Dan setelah dihitung, maka diperoleh biaya bahan baku langsung untuk jenis roti berwarna hijau adalah 2.163,162 Rp/bungkus, untuk jenis roti tanpa kulit adalah 2.163,162 Rp/bungkus dan untuk jenis roti berkulit adalah 2.163,162 Rp/bungkus. Untuk biaya tenaga kerja langsung maka diperoleh untuk jenis roti berwarna hijau adalah 70/bungkus, untuk jenis roti tanpa kulit adalah 70/bungkus dan untuk jenis roti berkulit adalah 70/bungkus. Untuk biaya overhead pabrik maka diperoleh untuk setiap jenis roti adalah Rp.443,79/bungkus.

3. Analisa Perhitungan Harga Pokok Produksi

Pada langkah perhitungan harga pokok produksi, maka diperoleh HPP untuk tiap jenis roti adalah Rp.2.422,932. Karena tujuan dari KP ini adalah memaksimumkan keuntungan dengan metode linear programming, maka keuntungan yang dihitung adalah marginal income. Sehingga marginal income untuk jenis roti berwarna hijau adalah Rp.6.077, untuk jenis roti tanpa kulit adalah Rp.6.577, dan untuk jenis roti berkulit adalah Rp.5.575.

4. Analisa Perhitungan dengan Menggunakan Linear Programming

Dengan menggunakan alat bantu software TORA untuk penyelesaian yang lebih cepat, tepat dan teliti. Hasilnya dapat dilihat di lampiran, maka diperoleh hasil optimum yaitu, CV Aceh Bakery harus memproduksi jenis roti berwarna hijau dengan jumlah 152 bungkus/hari, untuk jenis roti tanpa kulit sebanyak 149 
bungkus/hari, dan untuk jenis roti berkulit sebanyak 150 bungkus/hari. Sehingga diperoleh keuntungan sebesar Rp.1.973.100,-/hari.

\section{KESIMPULAN}

Berdasarkan hasil penelitian dan pembahasan yang dilakukan, maka dapat disimpulkan bahwa jumlah tiap jenis roti yang harus diproduksi oleh CV. Aceh Bakery sehingga dapat menghasilkan keuntungan yang maksimal sesuai dengan sumber daya yang tersedia. Untuk jenis roti berwarna hijau, CV. Aceh Bakery harus memproduksi sebanyak 152 bungkus/hari. Untuk jenis roti tanpa kulit, CV. Aceh Bakery harus memproduksi sebanyak 149 bungkus/ hari. Untuk jenis roti berkulit, CV. Aceh Bakery harus memproduksi sebanyak 150 bungkus/hari. Dengan demikian, maka CV. Aceh Bakery akan mendapatkan keuntungan sebesar Rp.1.973.100,-/hari.

\section{DAFTAR PUSTAKA}

Don T philip. 1996. Operational Research and Principle. Edisi kelima. Penerbit PT Gramedia pustaka. Jakarta.

Eddy Herjanto. 1997. Manajemen Produksi dan Operasi. Gramedia widiasarana indonesia. Jakarta.

Henry Simamura. 2002. Akuntasi Manajemen. Penerbit Salembada empat. Jakarta.

Mulyadi. 2000. Akuntansi Biaya. Edisi lima. UGM. Yogyakarta.

Nasendi dan Affendy anwar. 1985. Program Linier dan Variannya. Edisi pertama. Penerbit PT Gramedia. Intitut Pertanian Bogor. Jakarta.

Pangestu subaggyo, Narwan asri, T. Hari handoko. 1983. Dasar-dasar Operation research. Edisi II. BPFE Yogyakarta.

Siringoringo, Hotniar. Seri Teknik Riset Operasional. 2005. Pemograman Linear. Penerbit Graha Ilmu. Yogyakarta.

Siswanto sutojo. 2001. Menyusun Strategi Harga. PT Damar Mulia Pustaka. Jakarta.

Siswanto. 2007. Operations Research. Jilid I. Erlangga. Jakarta. 